\title{
Hubungan Tingkat Kecemasan dalam Menghadapi UKMPPD OSCE dengan Nilai UKMPPD Mahasiswa Fakultas Kedokteran Universitas Sam Ratulangi
}

\author{
${ }^{1}$ Gilbert Limen, ${ }^{2}$ Joshua Runtuwene, ${ }^{2}$ Christillia Wagiu \\ ${ }^{1}$ Program Studi Pendidikan Dokter Fakultas Kedokteran Universitas Sam Ratulangi Manado \\ ${ }^{2}$ Medical Education Unit Fakultas Kedokteran Universitas Sam Ratulangi Manado \\ Email: limengilbert@gmail.com
}

\begin{abstract}
Exam is a potential stressor to cause anxiety among students. As an exit exam, the medical competency examination consists of two parts: multiple choice question computerbased test and an objective structured clinical examination (OSCE). The anxiety level during the latter part where the cognitive, psychomotor and professional behaviour aspects of examinees are tested, is considered the highest. Passing grade of the exam as one criterion used for important decisions can also be another source of anxiety. Anxiety may impact performance during exam and consequently the passing grade. This study was aimed to evaluate the correlation between the anxiety level right before medical competency examination OSCE and the August 2018 OSCE final results. This was an analytical study with a cross sectional design. Respondents were all students partaking in OSCE at Sam Ratulangi University Medical School. The Hamilton Anxiety Rating Scale was used to measure the anxiety level. The OSCE results were retrieved from the Academic Department. Data were analyzed with the Spearman correlation test that obtained a $P$ value of 0.289 . Overall, $81.20 \%$ of respondents experienced anxiety, however, the majority (43.50\%) were considered as mild anxiety. Moreover, the median score of August 2018 OSCE was 80.00. Conclusion: There is no correlation between anxiety level right before OSCE and August 2018 final results.
\end{abstract}

Keywords: anxiety level, medical competency examination, OSCE score

\begin{abstract}
Abstrak: Ujian dapat menjadi sebuah stresor yang menimbulkan kecemasan. Uji Kompetensi Mahasiswa Program Profesi Dokter (UKMPPD) sebagai exit exam terdiri atas dua jenis ujian yakni pilihan ganda berbasis komputer dan Objective Structured Clinical Examination (OSCE). Tingkat kecemasan yang dihasilkan oleh OSCE paling tinggi karena OSCE menguji aspek kognitif, psikomotor dan professional behavior. Nilai batas lulus ujian UKMPPD juga dapat menjadi sumber kecemasan karena digunakan untuk menentukan keputusan yang penting. Kecemasan dalam menghadapi ujian dapat menjadi salah satu penyebab yang memengaruhi performa dan berdampak pada kelulusan. Penelitian ini bertujuan untuk mengetahui hubungan tingkat kecemasan mahasiswa dalam menghadapi UKMPPD OSCE dengan nilai UKMPPD OSCE periode Agustus 2018. Jenis penelitian ialah analitik dengan desain potong lintang. Responden ialah seluruh mahasiswa yang mengikuti UKMPPD OSCE di Fakultas Kedokteran Universitas Sam Ratulangi (Unsrat) dengan menggunakan instrumen penelitian Hamilton Anxiety Rating Scale untuk mengukur tingkat kecemasan dan nilai OSCE dari Bagian Akademik Fakultas Kedokteran Unsrat. Analisis statistik menggunakan uji korelasi Spearman. Hasil analisis hubungan antara kecemasan dalam menghadapi UKMPPD OSCE dengan nilai UKMPPD OSCE periode Agustus 2018 mendapatkan nilai $P=0,289$. Responden yang mengalami kecemasan sebanyak $81,20 \%$ dan umumnya memiliki tingkat kecemasan yang ringan (43,50\%). Median nilai UKMPPD OSCE periode Agustus 2018 yang diperoleh ialah 80,00. Simpulan: Tidak terdapat hubungan antara tingkat kecemasan dalam menghadapi UKMPPD OSCE dengan nilai UKMPPD OSCE periode Agustus 2018.
\end{abstract}

Kata kunci: tingkat kecemasan, UKMPPD, nilai OSCE 
Kecemasan adalah suatu bentuk emosi negatif yang dapat timbul dalam berbagai keadaan dan situasi, biasanya dicetuskan oleh objek ancaman yang tidak nyata secara fisik. ${ }^{1}$ Ujian dapat menjadi sebuah stresor atau stimulus yang dapat menyebabkan terjadinya kecemasan. Kecemasan yang timbul pada saat ujian, yang biasanya disebut sebagai uji kecemasan (test anxiety) adalah suatu keadaan psikologis saat orang merasa cemas dalam menghadapi suatu proses evaluasi atau ujian. ${ }^{2}$

Uji Kompetensi Mahasiswa Program Profesi Dokter (UKMPPD) merupakan suatu exit exam yang berskala nasional bagi mahasiswa program profesi dokter sebelum mengangkat sumpah sebagai dokter. Posisi UKMPPD sebagai exit exam dapat menjadi sumber kecemasan bagi mahasiswa. Uji kompetensi ini terdiri dari 2 jenis uji, yaitu pilihan jamak/multiple choice question (MCQ) menggunakan komputer (Computer Based Test/CBT) dan uji keterampilan pemeriksaan klinis (Objective Structured Clinical Examination/OSCE). ${ }^{3}$

Selain aspek kognitif, aspek psikomotor, kognitif, dan professional behavior juga diuji dalam OSCE. Banyaknya beban pikiran tentang materi yang harus dipelajari, perlunya integrasi antara teori, skill dan clinical reasoning dalam ujian OSCE, suasana ujian OSCE, penguji OSCE yang mengobservasi secara langsung hal yang dilakukan oleh peserta, ketidaksiapan mahasiswa dalam mengikuti OSCE, mekanisme ujian OSCE serta interval waktu yang sama setiap stasiun menjadikan OSCE sebagai ujian dengan tingkat kecemasan paling tinggi. ${ }^{4-6}$

Nilai dapat menjadi suatu sumber kecemasan dalam ujian terutama pada saat nilai tersebut digunakan untuk menentukan suatu keputusan yang penting. Nilai Batas Lulus (NBL) dalam UKMPPD dapat menjadi sumber kecemasan mahasiswa karena berkaitan dengan kelulusan dalam UKMPPD. Hal ini menjadi sebuah tuntutan bagi mahasiswa untuk memperoleh nilai yang baik. ${ }^{7}$ Nilai juga menjadi suatu kriteria yang menunjukkan tingkat kesuksesan mahasiswa selama pendidikan sehingga sangat penting untuk memahami berbagai faktor yang memengaruhi, memrediksi atau menyebabkan variasi nilai. ${ }^{8}$

Banyak penelitian yang menunjukkan bahwa uji kecemasan memiliki efek negatif terhadap performa akademik seseorang. Hal ini pertama kali ditunjukkan oleh penelitian yang dilakukan di Universitas Yale pada tahun 1952 yang melaporkan bahwa mahasiswa dengan tingkat kecemasan rendah mengungguli teman mereka dengan tingkat kecemasan tinggi pada suatu tes intelegensi. ${ }^{9}$ Penelitian lanjut umumnya juga menunjukkan hasil yang serupa. Meskipun demikian, penelitian yang dilakukan pada tahun 2016 terhadap 107 mahasiswa yang akan mengikuti OSCE di Fakultas Kedokteran Gigi Universitas Islam Sultan Agung mendapatkan bahwa tidak terdapat hubungan antara tingkat kecemasan dengan nilai OSCE. ${ }^{10}$ Penelitian pada 61 mahasiswa di Fakultas Kedokteran Universitas Gadjah Mada juga melaporkan bahwa tidak terdapat hubungan antara tingkat kecemasan dengan nilai OSCE. ${ }^{11}$ Oleh sebab itu, simpulan selintas mengenai hubungan antara performa dan tingkat kecemasan yang dialami perlu ditinjau kembali terutama dalam hal UKMPPD OSCE.

Penelitian ini bertujuan untuk mengetahui hubungan antara tingkat kecemasan dalam menghadapi UKMPPD OSCE dengan nilai UKMPPD OSCE di Fakultas Kedokteran Universitas Sam Ratulangi (FK Unsrat).

\section{METODE PENELITIAN}

Jenis penelitian ini ialah analitik dengan desain potong lintang. Teknik pengambilan sampel pada penelitian ini menggunakan total sampling. Karakteristik subyek penelitian yang harus dipenuhi ialah mahasiswa FK Unsrat yang terdaftar sebagai peserta UKMPPD OSCE periode Agustus 2018, telah mengikuti briefing, serta mengisi informed consent dan lembar kuesioner penelitian.

Tingkat kecemasan dalam menghadapi UKMPPD OSCE merupakan variabel independen dan nilai UKMPPD OSCE merupa- 
kan variabel dependen. Instrumen penelitian yang digunakan ialah informed consent dan lembar kuesioner penelitian yang terdiri dari dua bagian yakni identitas responden dan Hamilton Anxiety Rating Scale (HARS). Data penelitian dianalisis menggunakan uji korelasi Spearman.

\section{HASIL PENELITIAN}

Mahasiswa FK Unsrat yang mengikuti UKMPPD periode Agustus 2018 serta memenuhi kriteria pada penelitian ini berjumlah 69 dari total 73 responden penelitian. Response rate dalam penelitian ini yakni 94,52\%. Tiga peserta UKMPPD OSCE tidak hadir pada saat briefing dan satu peserta tidak bersedia mengikuti penelitian.

Tabel 1 memperlihatkan bahwa tingkat kecemasan sebagian besar mahasiswa yang akan mengikuti UKMPPD OSCE periode Agustus 2018 setelah dikategorikan ialah kecemasan ringan $(43,50 \%)$ sedangkan kecemasan sedang ialah tingkat kecemasan kedua terbanyak $(29,00 \%)$.

Tabel 1. Distribusi frekuensi kategori tingkat kecemasan mahasiswa dalam menghadapi UKMPPD OSCE periode Agustus $2018(\mathrm{n}=69)$

\begin{tabular}{lcc}
\hline Tingkat kecemasan & n & \% \\
\hline Tidak ada kecemasan & 13 & 18,80 \\
Kecemasan ringan & 30 & 43,50 \\
Kecemasan sedang & 20 & 29,00 \\
Kecemasan berat & 6 & 8,70 \\
Total & 69 & 100,00 \\
\hline
\end{tabular}

Keterangan: $n=$ jumlah responden

Tabel 2 memperlihatkan nilai tengah dari tingkat kecemasan mahasiswa dalam menghadapi UKMPPD OSCE $(n=69)$ ialah 11,00 (0-37) sedangkan nilai maksimum UKMPPD OSCE periode Agustus 2018 mahasiswa Fakultas Kedokteran Unsrat dalam persen $(n=69)$ yaitu 91,18 dengan median yaitu 80,00 (55,11-91,18). Hasil analisis hubungan antara tingkat kecemasan dengan nilai UKMPPD OSCE periode Agustus 2018 menggunakan uji korelasi Spearman (tingkat kemaknaan 0,05) memperoleh nilai $P=0,289(P>0,05)$. Hal ini menunjukkan bahwa tidak terdapat hubungan antara tingkat kecemasan dalam menghadapi UKMPPD OSCE dan nilai UKMPPD OSCE. Selain itu, nilai korelasi Spearman sebesar 0,129 menunjukkan kekuatan korelasi sangat lemah.

Tabel 2. Hubungan antara tingkat kecemasan mahasiswa dalam menghadapi UKMPPD OSCE periode Agustus 2018 dianalisis dengan uji korelasi Spearman

\begin{tabular}{lcccc}
\hline & Median & $\mathbf{r}$ & $\begin{array}{c}\text { Nilai } \\
\boldsymbol{P}\end{array}$ & $\mathbf{n}$ \\
\hline Tingkat & 11,00 & 0,129 & 0,289 & 69 \\
Kecemasan & & & & \\
Nilai OSCE & 80,00 & & & \\
\hline
\end{tabular}

Keterangan: $\mathrm{n}=$ jumlah sampel; Nilai $p=$ nilai signifikansi; $r=$ koefisien korelasi

\section{BAHASAN}

Hasil penelitian ini memperlihatkan bahwa mayoritas mahasiswa yang menghadapi UKMPPD OSCE memiliki tingkat kecemasan ringan (Tabel 1). Hal ini didukung oleh penelitian sebelumnya di Fakultas Kedokteran Udayana yang meneliti tingkat kecemasan 133 mahasiswa diukur menggunakan HARS. Hasil penelitian tersebut mendapatkan bahwa $72,90 \%$ mahasiswa mengalami kecemasan, dan $58,70 \%$ memiliki tingkat kecemasan ringan. ${ }^{12}$

Hasil berbeda dilaporkan oleh penelitian yang dilakukan terhadap 101 mahasiswa kedokteran di Amerika Serikat yang akan mengikuti United States Medical Licensing Examination (USMLE) dengan menggunakan Westside Test Anxiety. Sebanyak 22\% mahasiswa memiliki tingkat kecemasan sedang sampai tinggi. ${ }^{13}$ Penelitian yang dilakukan pada 104 mahasiswa kedokteran Babol Midwifery College dalam menghadapi ujian komprehensif juga menunjukkan hasil yang berbeda. Test Anxiety Inventory digunakan untuk mengukur tingkat kecemasan dan didapatkan hasil bahwa sebagian besar mahasiswa memiliki tingkat kecemasan sedang $(59,60 \%){ }^{14}$

Kecemasan yang terjadi dapat diakibatkan oleh faktor akademik, sosial, psikologis, gaya hidup, dan situasional. Mahasiswa kedokteran harus melewati NBL 
yang terstandar untuk menunjukkan mutu dan kompetensi serta untuk keperluan sertifikasi melalui ujian yang sekarang dikenal sebagai UKMPPD sesuai dengan Undang-Undang Praktik Kedokteran No.29 tahun 2004 dan Peraturan Konsil Kedokteran Indonesia No.1 Tahun 2010. ${ }^{15,16}$ Setiap lulusan dokter yang ingin melakukan praktik kedokteran harus memiliki izin praktik dokter yang diberikan jika dokter melampirkan sertifikat kompetensi saat melakukan registrasi di Konsil Kedokteran Indonesia. ${ }^{17}$

Mahasiswa yang berhak mengikuti UKMPPD ialah mahasiswa yang telah menyelesaikan seluruh rotasi klinik di rumah sakit sehingga seharusnya telah mendapatkan seluruh materi dalam Standar Kompetensi Dokter Indonesia (SKDI) 2012. Pelaksanaan UKMPPD selalu berdasarkan blue print yang seimbang dan proporsional pada SKDI 2012. Hal ini menunjukkan bahwa materi yang harus dipelajari sangat banyak sehingga berdampak pada tingkat kecemasan mahasiswa. ${ }^{18}$ Di sisi lain, hal ini juga berarti bahwa mahasiswa yang akan mengikuti UKMPPD sudah menyelesaikan pendidikan profesi yang dalam pelaksanaannya memperbolehkan mahasiswa untuk terlibat dalam pelayanan kesehatan dengan bimbingan dan supervisi dosen. Mahasiswa dapat melakukan latihan dan mendapat pengalaman dengan melakukan praktik kedokteran. Pengalaman ini dapat meningkatkan kepercayaan diri dalam melakukan ketrampilan yang akhirnya akan memengaruhi tingkat kecemasan dalam OSCE. ${ }^{19}$

Mekanisme ujian OSCE juga dapat menjadi sumber kecemasan bagi mahasiswa mulai dari pertanyaan, topik ujian, situasi, penguji dan peralatan dalam ujian. ${ }^{10,20}$ Frekuensi keikutsertaan mahasiswa dalam UKMPPD juga memengaruhi kecemasan. Semakin banyak seseorang mengikuti UKMPPD maka semakin tinggi juga kecemasan yang dialami. Retaker cenderung takut untuk gagal lagi dan selalu berpikir bahwa dirinya belum siap. ${ }^{12}$

Fakultas Kedokteran Unsrat pada tahun 2007 menerapkan Kurikulum Ber- basis Kompetensi (KBK) yang memasukkan skill laboratorium sejak semester 3 sampai semester 7 serta ujian sumatif OSCE di setiap akhir semester. Luaran yang diharapkan ialah mahasiswa dapat memperoleh lebih banyak latihan dengan format ujian OSCE dan lebih familiar dengan tipe pertanyaan yang mungkin muncul dalam ujian OSCE. Mahasiswa yang memiliki banyak persiapan dan lebih rileks akan memiliki performa yang lebih baik karena kecemasan akan ujian OSCE mereka lebih berkurang. ${ }^{21}$ Meskipun demikian, efek yang dihasilkan dengan adanya skill laboratorium tergantung dari institusi, dosen dan mahasiswa. Lingkungan pembelajaran dapat memengaruhi pembelajaran mahasiswa yang berdampak pada tingkat kecemasan saat menghadapi ujian. ${ }^{22,23}$

SKDI 2012 juga mulai diperkenalkan sejak semester 1 dan selalu diingatkan kembali di setiap modul pembelajaran. Hal ini membuat mahasiswa dapat mengetahui konten yang akan diuji saat UKMPPD dan sejauh mana suatu keterampilan dapat dilakukan pada saat ujian. Penjelasan mengenai format dan konten dari OSCE akan memengaruhi tingkat kecemasan mahasiswa dalam menghadapi OSCE. ${ }^{24}$

Seseorang akan melakukan berbagai macam cara agar dapat mengatasi keadaan yang menyebabkan stres yang disebut sebagai koping. Mekanisme koping terdiri dari koping adaptif dan maladaptif yang diterapkan dengan strategi serta memiliki efek yang berbeda pada setiap individu. Oleh karena itu, tingkat kecemasan yang dialami setiap individu dalam menghadapi ujian pasti berbeda-beda. ${ }^{25}$ Jenis kelamin, usia, tingkat pendidikan orang tua serta pikiran yang negatif dan tidak rasional tentang ujian, hasil ujian, dan cenderung mengritik diri sendiri dapat memengaruhi tingkat kecemasan. ${ }^{26,27}$ Selain itu, faktor nutrisi, aktivitas fisik, dan istirahat yang cukup juga dapat menjadi faktor yang berpengaruh. ${ }^{26}$ Tingkat kecemasan mahasiswa dalam penelitian ini diukur sesaat sebelum ujian OSCE sehingga memberikan stresor tambahan yang menyebabkan responden cenderung untuk melaporkan 
tingkat kecemasan mereka berdasarkan rasa terganggu akibat tugas tambahan untuk mengisi kuesioner yang diberikan. Terdapat kemungkinan bahwa tingkat kecemasan responden penelitian dalam menghadapi UKMPPD OSCE tidak tergambarkan secara utuh. ${ }^{28,29}$ Selain itu, setiap responden berbeda dalam kemampuan dan kemauan untuk mengekspresikan tingkat kecemasannya. $^{30}$ Perlu diperhatikan juga bahwa instrumen yang digunakan untuk mengukur tingkat kecemasan seseorang sangat beragam sehingga dapat menghasilkan tingkat kecemasan yang berbeda pula. ${ }^{29}$

Median nilai UKMPPD OSCE periode Agustus 2018 yaitu 80,00\% dengan nilai maksimum $91,18 \%$. Nilai batas lulus ujian untuk UKMPPD periode Agustus 2018 ialah 66 untuk CBT dan 29,32 (68,98\%) untuk OSCE. Oleh karena itu, umumnya peserta UKMPPD OSCE periode Agustus 2018 sudah melewati NBL untuk periode ini. Hasil ini sesuai dengan penelitian sebelumnya pada 110 mahasiswa yang akan mengikuti UKMPPD di Universitas Sam Ratulangi yakni mayoritas responden memiliki nilai OSCE di atas NBL. ${ }^{31}$

Posisi UKMPPD sebagai exit exam menyebabkan peserta uji kompetensi merupakan mahasiswa program profesi dokter yang telah menyelesaikan seluruh proses pembelajaran. Oleh sebab itu, peserta seharusnya sudah mendapatkan seluruh materi sesuai dengan SKDI tahun 2012 sehingga mampu untuk melewati NBL yang ditentukan. $^{31}$ Meskipun demikian, hal ini juga berdampak pada kompleksitas soal dan materi yang akan diuji, dimana ketrampilan yang akan diuji pasti lebih bervariasi, sulit, dan rumit. Di samping itu, UKMPPD sebagai exit exam menjadikan UKMPPD sebagai high-stake examination, karena memiliki konsekuensi yang penting. Konsekuensi dari suatu ujian akan memengaruhi usaha seseorang untuk berhasil dalam ujian tersebut. ${ }^{28}$

Skill laboratorium dan ujian sumatif OSCE dalam KBK juga memiliki pengaruh terhadap nilai yang diperoleh. Skill laboratorium dapat meningkatkan pengalaman mahasiswa namun keberhasilan penerapan- nya tetap tergantung dari dosen yang mengajar, institusi dalam menyediakan dan mempersiapkan fasilitas serta ketekunan mahasiswa untuk berlatih dan belajar. Ujian OSCE sendiri dapat memengaruhi cara belajar mahasiswa dalam menghadapi ujian serupa dan menjadi motivasi dalam mempelajari keterampilan klinik. ${ }^{32,33}$

Persepsi mahasiswa terhadap lingkungan pembelajaran dapat menunjang mahasiswa kedokteran dalam menghadapi ujian. Manifestasi nyata dari pelaksanaan kurikulum dan konseptualisasi dalam dunia akademik merupakan bagian dari lingkungan pembelajaran sehingga menjadi faktor eksternal yang dapat meningkatkan pencapaian mahasiswa dalam ujian. ${ }^{23}$

Jenis kelamin, usia, talenta, cara belajar, kemampuan manajemen waktu, dan kualitas hidup mahasiswa merupakan beberapa faktor individu yang dapat memengaruhi nilai yang diperoleh dalam ujian OSCE. ${ }^{18,21,22,34}$ Di samping itu, keadaan pada saat ujian OSCE seperti performa dari pasien standar, keadaan saat ujian OSCE yang tidak mirip dengan keadaan klinik, serta objektivitas dari penguji dalam menilai juga dapat memengaruhi nilai ujian. Secara garis besar, terdapat tiga faktor yang dapat memengaruhi nilai OSCE yakni kemampuan kognitif, non-kognitif, dan situasional.

Hasil analisis bivariat antara tingkat kecemasan dengan nilai UKMPPD OSCE periode Agustus 2018 menggunakan uji korelasi Spearman mendapatkan nilai $P$ $=0,289$ dan nilai korelasi Spearman sebesar 0,129 (Tabel 2). Hal ini berarti tidak terdapat hubungan antara tingkat kecemasan dalam menghadapi UKMPPD OSCE dengan nilai UKMPPD OSCE periode Agustus 2018 serta kekuatan korelasi yang sangat lemah. Hasil penelitian ini selaras dengan penelitian di Fakultas Kedokteran Gigi Universitas Islam Sultan Agung terhadap 135 mahasiswa yang mendapatkan bahwa tidak terdapat korelasi antara tingkat kecemasan dan nilai yang diperoleh. ${ }^{10}$ Penelitian tahun 2016 pada 103 mahasiswa di FK Universitas Gadjah Mada juga mendapatkan hasil yang serupa. ${ }^{11}$ 
Hamilton Anxiety Rating Scale (HARS) dibuat dengan cara mengumpulkan gejala-gejala kecemasan yang sering muncul dan kemudian dikategorikan berdasarkan sifat alamiah gejala itu atau pengalaman klinik. Debilitating test anxiety terdiri dari emotionality dan worry. Worry/ cognitive test anxiety adalah suatu pemikiran negatif tentang ujian ataupun hasil ujian itu sendiri dalam suatu suasana ujian yang dapat mempengaruhi seseorang dalam menghasilkan performa yang optimal. Dimensi lainnya yang dikenal sebagai emotionality/affective test anxiety adalah suatu kesadaran individu yang subjektif terhadap bangkitan otonom akibat reaksi otonom itu sendiri. Oleh sebab itu, penggunaan HARS pada dasarnya hanya mengukur dimensi emotionality seseorang dalam test anxiety dan tidak bisa mengukur dimensi worry. ${ }^{9,35}$ Emotionality yang tinggi dapat diikuti dengan worry yang tinggi atau rendah namun worry hanya akan muncul setelah individu memiliki emotionality yang tinggi. Worry yang tinggi merupakan prediktor utama dari performa seseorang. Dalam penelitian ini, terdapat kemungkinan bahwa peserta yang mendapatkan nilai tinggi pada saat mengalami kecemasan tinggi mungkin memiliki emotionality yang tinggi, tapi worry rendah sehingga tidak berdampak pada performa saat ujian.

Anxiety test memiliki dua dimensi yakni facilitating dan debilitating anxiety. Salah satu dimensi dari anxiety test tersebut akan menentukan perilaku yang muncul apakah task-directed atau task-irrelevant. ${ }^{9}$

Kecemasan tinggi dalam mengikuti UKMPPD OSCE yang merupakan highstake examination dapat memengaruhi hubungan antara tingkat kecemasan dengan nilai. Penelitian dalam pendidikan kedokteran menunjukkan bahwa mahasiswa dengan tingkat kecemasan tinggi akan memiliki nilai yang sama atau lebih dari mahasiswa dengan tingkat kecemasan yang lebih rendah pada high-stake examination. ${ }^{28}$ Mahasiswa peserta ujian OSCE tetap dapat menjawab pertanyaan dengan benar karena telah mempersiapkan dirinya dengan baik namun tingkat kecemasannya tetap tinggi pada saat menghadapi ujian. ${ }^{36}$ Di samping itu, banyak sekali riset yang menunjukkan bagaimana kecemasan mahasiswa memengaruhi performanya dalam multiple-choice atau ujian tertulis. ${ }^{37}$ Walaupun demikian, masih sangat sedikit informasi tentang hubungan tingkat kecemasan dan keberhasilan dalam ujian OSCE.

Pada umumnya, terdapat korelasi yang negatif antara tingkat kecemasan dan nilai ujian. Tingkat kecemasan yang tinggi akan menghasilkan nilai yang rendah dan tingkat kecemasan yang rendah dapat meningkatkan nilai. Hukum Yerkes-Dodson menyatakan bahwa terdapat hubungan yang berbentuk U terbalik antara arousal dan performa. Tingkat kecemasan berfungsi untuk meningkatkan performa tapi hanya sampai suatu titik tertentu sehingga level optimal dari kecemasan berada tepat di tengah dari kurva bukan di akhir ataupun di awal kurva. Namun, hukum ini tidak dapat dibuktikan pada saat diterapkan dalam pendidikan kedokteran dan penilaian. Hukum ini mempunyai keterbatasan pada saat dijadikan sebuah acuan karena tidak mencakup penyebab, persepsi, ataupun mekanisme koping dari individu. Di samping itu, hukum ini tidak spesifik untuk kecemasan ataupun stres, tapi lebih merujuk pada physiological arousal. ${ }^{22}$

Teori yang dapat menggambarkan lebih lengkap hubungan antara suatu tingkat kecemasan dan nilai yang dicapai dalam ujian OSCE ialah theory of cognitive appraisal. Teori ini mempertimbangkan konsekuensi yang dapat terjadi dan mekanisme koping yang berhubungan dengan ujian. Tingkat stres yang dialami seseorang terhadap suatu ujian berhubungan dengan bagaimana pandangannya terhadap ujian tersebut, apakah ujian bersifat sumatif atau formatif, atau ujian ini merupakan exit exam. Konsekuensi yang akan muncul berhubungan dengan stres yang dialami menjadi cikal bakal terbentuknya mekanisme koping yang adaptif atau maladaptif. ${ }^{22}$

Penelitian ini merupakan penelitian pertama di FK Unsrat sehingga dapat dijadikan bahan referensi bagi institusi dan peneliti selanjutnya. Penelitian ini sulit 
untuk digeneralisasi karena hanya menggunakan satu lokasi penelitian dan teknik pengambilan sampel ialah total sampling. Penelitian ini juga tidak mengontrol faktor perancu dan kemungkinan terdapat bias keinginan sosial karena kuesionar diisi oleh masing-masing subjek penelitian sesaat sebelum ujian OSCE UKMPPD. Desain penelitian yang potong lintang juga menyebabkan kausalitas antara dua variabel yang diteliti tidak dapat diketahui.

\section{SIMPULAN}

Berdasarkan hasil penelitian ini dapat disimpulkan bahwa tidak terdapat hubungan antara tingkat kecemasan dalam menghadapi UKMPPD OSCE dengan nilai UKMPPD OSCE periode Agustus 2018 di Fakultas Kedokteran Universitas Sam Ratulangi.

Sebagian besar mahasiswa yang akan mengikuti UKMPPD OSCE periode Agustus 2018 termasuk dalam tingkat kecemasan ringan. Selain itu, mayoritas nilai UKMPPD OSCE periode Agustus 2018 melewati nilai batas lulus ujian (NBL).

\section{SARAN}

Disarankan untuk melakukan penelitian kualitatif untuk mengetahui penyebab kecemasan pada mahasiswa yang akan menghadapi UKMPPD, faktor-faktor apa saja yang dapat memengaruhi nilai UKMPPD OSCE, serta faktor mana yang paling berpengaruh. Penelitian mengenai hubungan antara tingkat kecemasan dengan nilai UKMPPD OSCE juga masih dapat dilakukan dengan melakukan kontrol terhadap faktor-faktor perancu dalam penelitian dan menggunakan kuesioner yang dibuat untuk mengukur test anxiety seperti test anxiety inventory.

Ucapan terima kasih ditujukan kepada Dr. dr. Billy Kepel, M. Med Sc, dr. Windy M. V. Wariki, MSc, PhD, dr. Siemona E. L. Berhimpon, MARS, serta semua pihak baik secara langsung maupun tak langsung telah memberikan saran dan menumbuhkan ide dalam penulisan artikel ini.

\section{DAFTAR PUSTAKA}

1. Andriani P, Sofya PA. Tingkat kecemasan dalam menghadapi Objective Structured Clinical Examination (OSCE) (Studi pada Peserta UKMP2DG Unsyiah Periode II Tahun 2016). J Caninus Denstistry. 2016;1:26-31.

2.Zuckerman MDC. Emotions and Anxiety (Ple: Emotion) (1st ed). New York: Taylor \& Francis Ltd, 2015; p. 317, 321-325.

3. Implementasi Uji Kompetensi Nasional Bidang Kesehatan sebagai langkah konkrit penjaminan mutu pendidikan tinggi kesehatan [Internet]. RISTEKDIKTI. 2018 [cited 2018 Aug 29]. Available from: https://ristekdikti.go.id implementasi-uji-kompetensi-nasionalbidang-kesehatan-sebagai-langkahkonkrit-penjaminan-mutu-pendidikantinggi-kesehatan/

4. Pierre RB, Wierenga A, Barton M, Branday JM, Christie CD. Student evaluation of an OSCE in paediatrics at the University of the West Indies, Jamaica. BMC Med Educ. 2004;4(1):22.

5. Sarid O, Anson O, Bentov Y. Students' reactions to three typical examinations in health sciences. Adv Heal Sci Educ. 2005;10(4):291-302.

6. Risma GB. Kecemasan dalam Objective Structured Clinical Examination (OSCE). Agromed Unila. 2015;2(4): 419-24.

7. Bonaccio S, Reeve CL. The nature and relative importance of students' perceptions of the sources of test anxiety. Learn Individ Differ. 2010;20(6):617-25.

8. Kusin S. Leadership style of lecturer influence on academic performance of TVET student. J Resour Dev Manag. 2015;9.

9. Hembree R. Correlates, causes, effects, and treatment of test anxiety. Rev Educ Res. 1988;58(1):47-77.

10. Praptiningsih RS. Kecemasan mahasiswa menghadapi Objective Structural Clinical Examination (OSCE). Odonto Dent J. 2016;3(2).

11. Hapsari LE. Hubungan antara kecemasan ujian dengan nilai OSCE pada mahasiswa Blok 4.5 CCNS Program Studi Ilmu Keperawatan Fakultas Kedokteran UGM. 2016; Available from: http://etd. repository.ugm.ac.id/ index.php?mod= penelitian_detail\&sub=PenelitianDetail 
\&act=view\&typ=html\&buku_id=9995

1\&obyek_id=4

12. Wardhana CA, Westa IW. Prevalensi cemas pada mahasiswa kedokteran yang mengikuti uji kompetensi mahasiswa Program Profesi Dokter Di Fakultas Kedokteran Universitas Udayana. E-Jurnal Med Udayana. $2015 ; 4(3)$.

13. Green M, Angoff N, Encandela J. Test anxiety and United States Medical Licensing Examination scores. Clin Teach. 2016;13(2):142-6.

14. Faramarzi M, Pasha $H$, Bakhtiari $A$, Salmalian H, Delavar MA, Amiri FN, et al. Test anxiety in objective structured clinical examinations (OSCEs) compared with traditional assessment methods in undergraduate midwifery students. Health (Irvine Calif). 2013;5(12):2204-9.

15. Republik Indonesia. Undang-Undang Republik Indonesia Nomor 29 Tahun 2004 Tentang Praktik Kedokteran. Jakarta: Sekretariat Kabinet RI, 2004.

16. Reteguiz J-A. Relationship between anxiety and standardized patient test performance in the medicine clerkship. J Gen Intern Med. 2006;21(5):415-8.

17. ISMKI. Kajian UKDI oleh ISMKI. 2014. Available from: http://ismki.org/kajiandan-kertas- posisi-ismki-terhadap-ujikompetensi- mei-2014/.

18. Simran G, Sangeeta N, Lily W. Evaluation of examination anxiety status and its associated factors among first professional medical (MBBS) students. IJIMS. 2015;2(8):1-11.

19. Espinosa A. Test anxiety and moving examination in science laboratory classes. Pakistan J Psychol Res. 2015; 30(2):343-55.

20. Zartman RR, McWhorter AG, Seale NS, Boone WJ. Using OSCE-based evaluation: curricular impact over time. J Dent Educ. 2002;66(12):1323-30.

21. Kim KJ. Factors associated with medical student test anxiety in objective structured clinical examinations: a preliminary study. Int $\mathbf{J}$ Med Educ. 2016;7:424-7.

22. Lyndon MP, Strom JM, Alyami HM, Yu T-C, Wilson NC, Singh PP, et al. The relationship between academic assessment and psychological distress among medical students: a systematic review. Perspect Med Educ. 2014;3(6):405-18.

23. Tompodung LM, Widaty S, Widyahening IS. Perceptions of academic achievers and under-achievers on learning environment at Sam Ratulangi University, Indonesia. Adv Sci Lett. 2018; 24(9):6777-80.

24. Marshall G, Jones N. A pilot study into the anxiety induced by various assessment methods. Radiography. 2003;9(3):18591.

25. Handayani WP, Setiawan DI, Widayati RW. Faktor-faktor yang berhubungan dengan tingkat stres menghadapi Objective Structured Clinical Examination pada mahasiswa Ilmu Keperawatan Fakultas Ilmu Kesehatan Universitas Respati Yogyakarta. J Keperawatan Respati Yogyakarta. 2017;4(1):106-11.

26. Hashmat S, Hashmat M, Amanullah F, Aziz S. Factors causing exam anxiety in medical students. J Pak Med Assoc. 2008;58(4):167-70.

27. Kurt AS, Balci S, Kose D. Test anxiety levels and related factors: students preparing for university exams. J Pak Med Assoc. 2014;64(11):1235-9.

28. Colbert-Getz JM, Fleishman C, Jung J, Shilkofski N. How do gender and anxiety affect students' self-assessment and actual performance on a highstakes clinical skills examination? Acad Med. 2013;88(1):44-8.

29. Hadi MA, Ali M, Haseeb A, Mohamed MMA, Elrggal ME, Cheema E. Impact of test anxiety on pharmacy students' performance in Objective Structured Clinical Examination: a cross-sectional survey. Int J Pharm Pract. 2018;26(2):191-4.

30. Brannick MT, Erol-Korkmaz HT, Prewett M. A systematic review of the reliability of objective structured clinical examination scores. Med Educ. 2011; 45(12):1181-9.

31. Febrianti W, Memah M, Manoppo F. Hubungan IPK sarjana dan profesi dengan nilai CBT, OSCE, dan hasil UKMPPD di Fakultas Kedokteran Universitas Sam Ratulangi Periode Mei dan Februari 2017. eBm. 2017;5(2).

32. Furlong E, Fox P, Lavin M, Collins R. Oncology nursing students' views of a modified OSCE. Eur J Oncol Nurs. 
2005;9(4):351-9.

33. Byrne E, Smyth S. Lecturers' experiences and perspectives of using an objective structured clinical examination. Rev Esp Cir Ortop Traumatol. 2008;52(4): 283-9.

34. Khalaila R. The relationship between academic self-concept, intrinsic motivation, test anxiety, and academic achievement among nursing students: Mediating and moderating effects. Nurse Educ Today. 2015;35(3):432-8.

35. Cassady JC, Johnson RE. Cognitive test anxiety and academic performance. Contemp Educ Psychol. 2002;27(2):
$270-95$.

36. Kalantari M, Zadeh N, Agahi R, Navabi N, Hashemipour M, Nassab AG. Measurement of the levels anxiety, selfperception of preparation and expectations for success using an objective structured clinical examination, a written examination, and a preclinical preparation test in Kerman dental students. J Educ Health Promot. 2017; 6(1):28.

37. Longyhore DS. Pharmacy student anxiety and success with objective structured clinical examinations. Am J Pharm Educ. 2017;81(1):7. 